\title{
Figures and Tables
}

F I G U R E S

3.1. The Communist Party Central Military Commission, 1999

6.1. Interaction between Domestic Politics and the International Environment

10.1. Taiwan Affairs Policy Apparatus Minus Research, Analysis, and Intelligence Organs, 1998

10.2. Research, Analysis, and Intelligence Organs Associated with the Taiwan Affairs Leading Small Group, 1998

T A B L E S

4.1. Basic Statistics of China's Provincial-Level Units, 1997

5.1. China’s National Party Leadership, March $2000 \quad$ I25

6.1. Chinese Citizens' Recognition of International Organizations, $1995 \quad 157$

6.2. Nativist Dimensions of Chinese Nationalism, $2000 \quad 170$

$\begin{array}{ll}\text { 6.3. Perceptions of China's Status, } 1995 & 187\end{array}$ 
